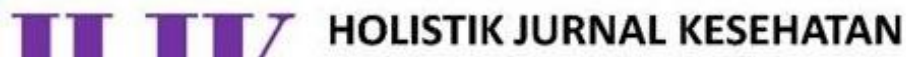 ISSN 1978-3337 (Print) ISSN 2620-7478 (Online)
}

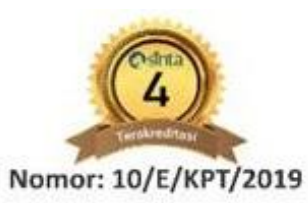

INFORMASI ARTIKEL

Received: February, 01, 2021

Revised: March, 15, 2021

Available online: March, 22, 2021

at : http://ejurnalmalahayati.ac.id/index.php/holistik

\section{Dukungan sosial dengan motivasi berhenti menggunakan narkoba pada klien rehab rawat jalan di Badan Narkotika Nasional (BNN) Provinsi Lampung}

\author{
Supriyati ${ }^{1 *}$, Mutia Pangesti² \\ 1Program Studi Psikologi Fakultas Kedokteran, Universitas Malahayati. *Email: supriyati@malahayati.ac.id \\ ${ }^{2}$ Psikologi Klinis Ahli Pertama Bid. Rehabilitasi BNN Provinsi Lampung
}

\begin{abstract}
Social support and motivation to quit on drugs abuse among psychosocial rehabilitation clients at National Narcotics Agency (NNA)
\end{abstract}

Background: The problem of illicit and drugs abuse in Indonesia is currently a disadvantage in developing the quality of human resources, especially the younger generation. Its condition has now reached an alarming level. In 2017, the prevalence of the number of drug abusers in Lampang Province reached 1.9\%, ranking 3rd out of 10 Provinces in Sumatra and 8th out of 34 Provinces in Indonesia. The biggest factor influencing to users to quit of drugs abuse such as social and family support.

Purpose: To determine the relationship between social support and motivation to quit on drugs abuse among psychosocial rehabilitation clients at National Narcotics Agency

Methods: A quantitative research with cross-sectional approach. The data collection method uses a social support scale consisting of 29 items and the motivation scale of 22 items. Analyzed using the Spearman Rank product moment. The sample was the client of outpatient rehabilitation at National Narcotics Agency and taken by purposive sampling technique and obtained a sample of 200 respondents.

Results: Finding of $r$ value of 0.058 with $P=0.408$, it means that there is a very significant positive relationship between social support and motivation to quit on drugs abuse among outpatient rehabilitation clients. The most respondents had of $62 \%$ of social support and of $55.5 \%$ had a motivation to quit on drugs abuse.

Conclusion: The social support and motivation to quit on drugs abuse among outpatient rehabilitation clients at National Narcotics Agency Lampang Province was a quite high.

Keywords: Social support; Motivation to quit; Drugs abuse; Psychosocial; Rehabilitation; Clients; National Narcotics Agency

Pendahuluan : Masalah peredaran gelap dan penyalahgunaan narkoba di Indonesia saat ini sudah menjadi hambatan dalam proses pembangunan kualitas sumber daya manusia khususnya generasi muda. Perkembangannya saat ini sudah mencapai tingkat yang mengkhawatirkan serta meresahkan khususnya para orang tua dan masyarakat pada umumnya. Tahun 2017 prevalensi jumlah penyalahguna Narkoba di Provinsi Lampung mencapai angka 1,9\% menempati urutan ke-3 dari 10 Provinsi di Sumatera dan urutan ke-8 dari 34 Provinsi di Indonesia. Faktor terbesar yang mempengaruhi keberhasilan pengguna narkoba untuk berhenti menggunakan narkoba adalah keluarga berbentuk dukungan sosial, dukungan sosial dalam hal ini adalah dukungan dari orangtua dan keluarga. Dukungan ini akan membantu pengguna narkoba untuk benarbenar dapat berhenti menggunakan narkoba dan meninggalkan pergaulan lamanya.

Tujuan: Diketahui hubungan antara dukungan sosial dengan motivasi berhenti menggunakan narkoba klien rehab rawat jalan di BNN Provinsi Lampung. 
Dukungan sosial dengan motivasi berhenti menggunakan narkoba pada klien rehab rawat jalan di Badan Narkotika Nasional (BNN) Provinsi Lampung

Metode : Penelitian kuantitatif dengan pendekatan cross-sectional. Metode pengumpulan data menggunakan skala dukungan sosial yang terdiri dari 29 item dan skala motivasi 22 item. Dianalisa menggunakan product moment Spearman Rank. Sampelnya klien rawat jalan Badan Narkotika Nasional dan diambil dengan teknik purposive sampling dan diperoleh sampel sebanyak 200 responden.

Hasil : Diperoleh hasil nilai $r$ sebesar 0,058 dengan $p=0,408$ dimana artinya ada hubungan positif yang sangat signifikan antara dukungan sosial dengan motivasi berhenti menggunakan narkoba pada klien rehab rawat jalan BNN Provinsi Lampung. Berdasarkan kategorisasi tingkat dukungan sosial mayoritas tinggi dan sangat tinggi dengan total jumlah dari kedua kategori tersebut sebanyak 124 (62\%). Untuk tingkat motivasi berhenti menggunakan narkoba mayoritas berada pada kategori sedang dan tinggi dengan jumlah sebanyak 111 responden dengan persentase $55.5 \%$.

Simpulan: Dukungan dan motivasi sosial untuk berhenti dari penyalahgunaan narkoba pada klien rehabilitasi rawat jalan di Badan Narkotika Nasional Provinsi Lampang cukup tinggi.

\section{Kata Kunci: Dukungan sosial; Motivasi; Narkoba; Klien; Rehabilitasi; Badan Narkotika Nasional}

\section{PENDAHULUAN}

Peredaran narkoba perkembangannya saat ini sudah mencapai tingkat yang mengkhawatirkan serta meresahkan khususnya para orang tua dan masyarakat umum. Meningkatnya jumlah tindakan ungkap kejahatan narkoba baik untuk pengguna maupun pengedar (Tarigan, 2017).

Mengkonsumsi narkoba tanpa ijin atau resep dokter merupakan suatu bentuk penyalahgunaan. Tindakan ini pada akhirnya dapat mengancam tidak hanya individu yang bersangkutan tetapi juga menjadi ancaman serius bagi kehidupan bangsa dan negara (Kementerian Kesehatan Republik Indonesia, 2017).

Kondisi individu sebagai pengguna narkoba dihadapkan dengan dua pilihan yang sangat menentukan kelanjutan hidup seseorang apakah akan tetap menggunakan narkoba dan menikmatinya, atau berhenti dengan segala konsekuensi, seperti dibenci teman sesama pengguna, tidak punya teman dan dikucilkan, dibenci oleh keluarga, malu dan merasa tidak punya harga diri, dan juga harus menahan rasa sakit yang luar biasa, cemas dan depresi, bahkan sampai muncul keinginan untuk bunuh diri (Weiss, Griffin \& Mirin, 1992).

Penyalahgunaan narkoba prevalensinya pada tahun 2015 menempatkan Provinsi Lampung di peringkat ke 33 jumlah penyalahguna Narkoba dari 34 Provinsi di Indonesia (Badan Narkotika Nasional Republik Indonesia, 2018). Untuk provinsi Lampung sendiri dengan jumlah penduduk 5.912.500 jiwa rentang usia 10-59 tahun, angka prevalensi telah mencapai $1,28 \%$ dari jumlah penduduk rentan. Hal ini berarti ada sekitar 74.224 orang penyalahguna narkoba di Provinsi Lampung. Tahun 2017 prevalensi jumlah penyalahguna Narkoba di Provinsi Lampung mencapai angka 1,9 $\%$ menempati urutan ke-3 dari 10 Provinsi di Sumatera dan urutan ke-8 dari 34 Provinsi di Indonesia (Badan Narkotika Nasional Republik Indonesia, 2018).

Survey awal data klien klinik Pratama BNNP Lampung periode Januari sampai Desember 2019 menunjukkan data yang fluktuatif dengan jumlah kasus sebanyak 524 kasus, dan terjadi peningkatan kasus lebih dari $50 \%$ pada bulan Juni - Juli pada tahun yang sama. Dengan rincian jumlah kasus laki-laki sebanyak 447 orang dan perempuan sebanyak 77 orang. Data tersebut menunjukkan kasus banyak dialami pada kelompok laki-laki dibandingkan pada kelompok wanita. Berdasarkan dari data usia pada jumlah pengguna narkoba yang menjalani rehab rawat jalan di BNN provinsi Lampung urutan pertama justru terjadi pada usia produktif yaitu usia antara 20-25 tahun, dilanjutkan urutan kedua dan ketiga pada usia 26-30 tahun dan 31-35 tahun (Badan Narkotika Nasional Provinsi Lampung, 2019).

Masyarakat di Indonesia sering menggunakan istilah napza, narkoba, narkotika dan obat terlarang untuk membicarakan hal-hal yang berkaitan dengan penyalahgunaan narkoba. Barang tersebut merupakan bahan atau zat yang jika masuk kedalam tubuh manusia akan mempengaruhi fungsi tubuh khususnya sistem saraf pusat. Kondisi tersebut akan menyebabkan gangguan fisik, psikis

\footnotetext{
Supriyati ${ }^{1 *}$, Mutia Pangesti ${ }^{2}$

'Program Studi Psikologi Fakultas Kedokteran, Universitas Malahayati. *Email: supriyati@malahayati.ac.id

${ }^{2}$ Psikologi Klinis Ahli Pertama Bid. Rehabilitasi BNN Provinsi Lampung
} 
Dukungan sosial dengan motivasi berhenti menggunakan narkoba pada klien rehab rawat jalan di Badan Narkotika Nasional (BNN) Provinsi Lampung

dan fungsi sosial (Kementerian Kesehatan Republik Indonesia, 2004).

Lima tingkatan pada pemakai narkoba, yaitu: (1) Pemakaian coba-coba ; pada fase ini pengguna hanya ingin mencoba untuk memenuhi rasa ingin tahu, tahapan ini ada sebagian yang berhenti namun ada juga yang berlanjut penggunaannya sampai pada tahap pecandu; (2). Pemakaian Sosial atau Rekreasi ; tujuan pada tahap ini hanya untuk bersenang-senang; (3). Pemakaian Situasional ; pada fase ini individu menggunakan narkoba saat mengalami situasi tertentu, misalnya saat berada dalam situasi ketegangan, kekecewaan, kesedihan dengan maksud untuk menghilangkan perasaan-perasaan tersebut; (4). Penyalahgunaan ; pada fase ini individu tidak mampu mengurangi apalagi menghentikan penggunaan narkoba, terus menggunakan meskipun fisiknya sudah mengalami perubahan akibat penggunaan narkoba; (5). Ketergantungan ; supaya tidak sampai pada fase ini sebaiknya pada fase sebelumnya perlu perhatian dari dari semua pihak khususnya dukungan keluarga Badan Narkotika Nasional Provinsi Lampung, 2016).

BNN memiliki program untuk rehabilitasi sebagai upaya pemulihan ketergantungan narkoba bagi pecandu dan/ atau korban penyalahgunaan, yang mencakup rehabilitasi medis, rehabilitasi sosial dan layanan pasca rehabilitasi yang dilakukan secara kontinu dalam satu kesatuan layanan yang terintegrasi (Kementerian Kesehatan Republik Indonesia, 2004).

Menurut UU RI No. 35 Tahun 2009 tentang Narkotika, ada dua jenis rehabilitasi, yaitu: (1) Rehabilitasi Medis adalah suatu proses kegiatan pengobatan secara terpadu untuk membebaskan pecandu dari ketergantungan narkotika; (2) Rehabilitasi Sosial adalah suatu proses kegiatan pemulihan secara terpadu, baik fisik, mental maupun sosial, agar bekas pecandu narkotika dapat kembali melaksanakan fungsi sosial dalam kehidupan masyarakat.

Individu yang mengkonsumsi narkoba akan mengalami gangguan mental dan perilaku sebagai akibat terganggunya neuron transmitter yang memungkinkan individu mengalami gangguan fungsi kognitif, afektif dan perilaku (Hawari, 2009).

Masalah penyalahgunaan narkoba memiliki dimensi luas dan komplek, baik aspek medis, psikiatri, maupun psikososial. Permasalahan tersebut berakibat pada tidak harmonisnya hubungan antara keluarga, menurunkan kemampuan belajar dan produktivitas kerja, tidak mampu membedakan mana yang baik serta mana yang buruk (Hawari, 2009). Keinginan untuk kembali hidup seperti manusia normal dan sehat, seorang pengguna haruslah mempertimbangkan segala konsekuensi yang mungkin terjadi, baik konsekuensi positif ataupun negatif, memilih satu diantara dua atau lebih alternatif bukanlah hal yang mudah (Nevid, Rathus, \& Greene, 1994). Salah satu upaya yang umumnya dilakukan seseorang ketika ada keinginan bisa melepaskan dan berhenti menggunakan narkoba mengarahkan individu maupun keluarga tergerak untuk mengikuti program rehabilitasi ataupun melakukan detoksifikasi (Somar, 2001). Lebih lanjut dijelaskan individu ketika menjalani proses rehabilitasi dihadapkan dengan program yang dapat membantu individu sembuh dari ketergantungan yang bukan hanya sekedar memulihkan kesehatan si pemakai tapi juga memulihkan serta menyehatkan individu secara utuh (Somar, 2001).

Dukungan sosial menjadi salah satu faktor yang mempengaruhi motivasi individu untuk sembuh dari penyalahgunaan narkoba. Pemberian dukungan sosial dari orang-orang yang berarti di sekitarnya khususnya keluarga memiliki sumbangan yang besar dalam meningkatkan harga diri individu. Dengan harga diri yang tinggi akan mempermudah proses penyembuhan. Sedangkan dukungan sosial yang kurang justru akan merendahkan serta tidak menghargai usaha yang sudah dilakukan individu yang pada akhirnya akan semakin tertekan yang berakibat pada proses rehabilitasi pada pengguna narkoba.

Faktor terbesar yang mempengaruhi keberhasilan pengguna narkoba untuk berhenti menggunakan narkoba adalah keluarga berupa dukungan sosial dalam hal ini adalah dukungan dari orang tua dan keluarga. Dukungan ini akan membantu pengguna narkoba untuk benar-benar dapat berhenti menggunakan narkoba dan meninggalkan pergaulan lamanya ( Afriani, \& Sari, 2017).

Motivasi adalah dorongan mental yang menggerakkan dan mengarahkan perilaku manusia (Rahmadani, 2020). Motivasi pada

\footnotetext{
Supriyati ${ }^{1 *}$, Mutia Pangesti ${ }^{2}$

'Program Studi Psikologi Fakultas Kedokteran, Universitas Malahayati. *Email: supriyati@malahayati.ac.id

${ }^{2}$ Psikologi Klinis Ahli Pertama Bid. Rehabilitasi BNN Provinsi Lampung
} 
Dukungan sosial dengan motivasi berhenti menggunakan narkoba pada klien rehab rawat jalan di Badan Narkotika Nasional (BNN) Provinsi Lampung

individu merupakan suatu dorongan dalam diri seseorang untuk berusaha mengadakan perubahan tingkah laku yang lebih baik dalam memenuhi kebutuhannya, (Uno, 2008).

Motivasi diartikan sebagai satu variabel penyelenggara yang digunakan untuk menimbulkan faktor-faktor tertentu pada organisme yang membangkitkan, mengelola, mempertahankan dan menyalurkan tingkah laku menuju satu sasaran (Chaplin, 2006). Lebih lanjut motivasi adalah keadaan pribadi individu yang mendorong keinginannya untuk melakukan kegiatan tertentu dalam mencapai suatu tujuan (Putra, 2011).

Tiga aspek dari motivasi seseorang : (1) Pengakuan terhadap masalah ; individu menyadari masalah dari penggunaan narkoba, yang disebabkan oleh kemungkinan dorongan intrinsik individu untuk terbebas dari narkoba; (2) Keinginan untuk dibantu ; Individu membutuhkan bantuan dari orang lain dalam hal ini keluarga menjadi komponen yang sangat berperan besar berupa semangat dan perhatian; (3)Kesiapan mengikuti treatment ; saat individu menyadari masalah saat menggunakan narkoba serta membutuhkan bantuan dari keluarga maka individu akan lebih siap dalam mengikuti rehabilitasi pada pengguna narkoba (Putra, 2011)

Dukungan sosial yang diberikan keluarga dapat berbentuk dukungan emosional, penghargaan, instrumental dan informasi (Sarafino \& Smith, 2014). Orang Tua berperan sebagai tokoh penting dengan siapa anak menjalin hubungan dan merupakan suatu sistem dukungan ketika anak menjajaki suatu dunia sosial yang lebih luas dan lebih kompleks. (Santrock, 2002). Bentuk dukungan sosial keluarga pada empat tipe dukungan, yaitu: (1) Dukungan Emosional, yang mencakup ungkapan empati, kepedulian dan perhatian terhadap orang yang bersangkutan; (2) Dukungan Penghargaan, terjadi melalui ungkapan hormat (penghargaan) positif, dorongan maju atau setuju dengan gagasan atau perasaan individu, dan perbandingan positif dengan orang lain; (3) Dukungan Instrumental, adalah bentuk dukungan yang meliputi pemberian nasehat, arahan, pertimbangan tentang bagaimana seseorang harus berbuat mencakup bantuan langsung, seperti memberi pinjaman uang; (4) Dukungan Informatif, mencakup memberikan nasehat, petunjuk, saran atau umpan balik sehingga dapat menolong individu untuk mengenali dan mengatasi masalah dengan mudah (Friedman, Kane. \& Cornfield, 1998).

Dukungan sosial memegang peranan penting dalam interaksi seseorang dengan orang lain. Empat fungsi dukungan sosial yang dapat membantu individu dalam menghadapi stres, yaitu : (1) Dukungan dapat berkontribusi secara positif dalam perasaan penghargaan dan diterima dengan membiarkan seseorang mengetahui bahwa individu dihargai, berguna, dan diterima; (2) Dukungan dapat membantu seseorang dalam menafsirkan, memahami dan menanggulangi penyebab tekanan kerja; (3) Dukungan sosial dapat memenuhi kebutuhan akan persahabatan yang dapat berkontribusi dalam perasaan memiliki dan membantu seseorang dari penyebab tekanan; (4) Dukungan sosial dapat menolong dengan cara memberikan sumber-sumber material dan pelayanan yang dibutuhkan seseorang untuk membantu menghadapi sumber tekanan (Wibowo, 2004).Setiap individu memiliki keinginan yang kuat untuk bisa lepas dari jeratan narkoba sehingga mereka memilih untuk bisa menjalani proses rehabilitasi sebagai proses untuk penyembuhan. Berdasarkan fenomena yang terjadi dukungan sosial yang berasal dari keluarga, sahabat, rekan kerja memiliki peranan besar dalam membantu proses rehabilitasi para pengguna narkoba. Hasil penelitian sebelumnya , menunjukkan ada hubungan antara Dukungan Sosial dengan Motivasi untuk Sembuh pada Pengguna Narkoba dengan nilai korelasi sebesar 0,435 dengan signifikansi 0,001 dimana $P<0,01$.

\section{METODE}

Penelitian ini menggunakan pendekatan kuantitatif dengan rancangan penelitian menggunakan cross sectional dengan teknik purposive sampling. Populasi penelitian adalah Klien Rehab Rawat Jalan di BNN Provinsi Lampung dengan jumlah Sampel penelitian 200 klien yang sedang menjalankan rehab rawat jalan dari bulan Januari - Juli 2020. Penelitian ini sudah dilakukan uji laik etik dengan nomor surat 1026/EC/KEP-UNMAL/NII/2020.

\footnotetext{
Supriyati ${ }^{1 *}$, Mutia Pangesti ${ }^{2}$

'Program Studi Psikologi Fakultas Kedokteran, Universitas Malahayati. *Email: supriyati@malahayati.ac.id

${ }^{2}$ Psikologi Klinis Ahli Pertama Bid. Rehabilitasi BNN Provinsi Lampung
} 
Dukungan sosial dengan motivasi berhenti menggunakan narkoba pada klien rehab rawat jalan di Badan Narkotika Nasional (BNN) Provinsi Lampung

Motivasi adalah skor yang diperoleh dari skala motivasi untuk berhenti menggunakan narkoba yang berdasarkan pengakuan terhadap masalah, keinginan untuk dibantu, dan kesiapan mengikuti treatment (Putra, 2011). Dukungan Sosial adalah skor dari skala berdasarkan teori yang diikembangkan oleh (Friedman, Kane. \& Cornfield, 1998).Prosedur penelitian diperoleh dari data primer dengan memberikan skala kepada subjek penelitian. Skala yang diberikan berbentuk skala Likert dengan menggunakan 4 alternatif jawaban, yaitu:sangat setuju (SS), setuju (S), tidak setuju (TS), dan sangat tidak setuju (STS). Pernyataanpernyataan tersebut ada yang bersifat favourable dan ada yang bersifat favourable.Untuk item favourable, skor subjek dimulai dari 4,3,2,1.Sementara untuk item unfavorable, skor subjek dimulai dari 1,2,3,4 (Azwar,
2013).Penelitian ini menggunakan kuesioner yang sudah di uji validitas oleh peneliti . uji validitas di lakukan di tempat yang sama dengan responden yang berbeda dan mendapatkan hasil uji validitas terhadap skala Dukungan Sosial terdapat 29 item yang valid dari 35 item semula yang memiliki skor corrected item total correlation yang bergerak dari 0,301 - 0,745. Sedangkan untuk skala Motivasi Berhenti Menggunakan narkoba terdapat 22 item yang valid dari 27 item semula dengan skor corrected item total correlation yang bergerak dari 0,303-0,775

Berdasarkan hasil uji reliabilitas dengan menggunakan rumus alpha cronbach diperoleh skor sebesar 0,911 untuk skala Dukungan Sosial dan 0,882 untuk skala Motivasi Berhenti Menggunakan Narkoba. Hal ini dapat dikatakan bahwa kedua skala tersebut dinyatakan reliable.

\section{HASIL}

Table 1. Karakteristik Responden Pengguna Narkoba ( $N=200)$

\begin{tabular}{|c|c|c|c|}
\hline Variabel & $\mathrm{n}$ & $\%$ & MISD \\
\hline \multicolumn{4}{|c|}{ Data Demografi Responden } \\
\hline Umur (tahun) (rentang) 15-56 & 200 & 100 & $29.18 \pm 9.637$ \\
\hline Lama Penggunaan Narkoba (tahun) (rentang) $1-10$ & 200 & 100 & $4.19 \pm 2.663$ \\
\hline \multicolumn{4}{|l|}{ Jenis Kelamin: } \\
\hline Laki-laki & 157 & 78 & \\
\hline Perempuan & 43 & 22 & \\
\hline \multicolumn{4}{|l|}{ Pendidikan : } \\
\hline Tidak Sekolah & 4 & 2 & \\
\hline SD & 20 & 10 & \\
\hline SMP & 52 & 26 & \\
\hline SMA & 85 & 42 & \\
\hline PT & 39 & 20 & \\
\hline \multicolumn{4}{|l|}{ Pekerjaan : } \\
\hline Wiraswasta & 92 & 46 & \\
\hline Swasta & 32 & 16 & \\
\hline Buruh & 31 & 15 & \\
\hline Mahasiswa & 17 & 9 & \\
\hline PNS & 14 & 7 & \\
\hline Tidak bekerja & 14 & 7 & \\
\hline
\end{tabular}

\section{Supriyati ${ }^{1 *}$, Mutia Pangesti ${ }^{2}$}

'Program Studi Psikologi Fakultas Kedokteran, Universitas Malahayati. *Email: supriyati@malahayati.ac.id

${ }^{2}$ Psikologi Klinis Ahli Pertama Bid. Rehabilitasi BNN Provinsi Lampung

DOI: https://doi.org/10.33024/hjk.v15i1.3791 
Dukungan sosial dengan motivasi berhenti menggunakan narkoba pada klien rehab rawat jalan di Badan Narkotika Nasional (BNN) Provinsi Lampung

\begin{tabular}{|c|c|c|}
\hline \multicolumn{3}{|l|}{ Status Perkawinan: } \\
\hline Menikah & 59 & 29.5 \\
\hline Belum menikah & 96 & 48.0 \\
\hline Cerai & 45 & 22.5 \\
\hline \multicolumn{3}{|l|}{ Tempat Tinggal: } \\
\hline Bersama orang tua/keluarga & 111 & 55.5 \\
\hline Sendiri & 89 & 44.5 \\
\hline \multicolumn{3}{|c|}{ Data Penggunaan Narkoba Dan Rehabilitasi } \\
\hline \multicolumn{3}{|c|}{ Pernah Mengikuti Program Rehabilitasi: } \\
\hline Pernah & 111 & 55.5 \\
\hline Tidak pernah & 89 & 44.5 \\
\hline \multicolumn{3}{|c|}{ Berapa Kali Mengikuti Rehabilitasi: } \\
\hline 1 kali & 54 & 48.6 \\
\hline 2 kali & 35 & 31.6 \\
\hline 3 kali & 22 & 19.8 \\
\hline \multicolumn{3}{|c|}{ Jenis Narkoba Yang Digunakan: } \\
\hline Sabu & 116 & 58.0 \\
\hline Ganja & 61 & 30.5 \\
\hline Obat terlarang & 23 & 11.5 \\
\hline \multicolumn{3}{|l|}{ Cara Penggunaan Narkoba : } \\
\hline Dihisap & 96 & 48.0 \\
\hline Dihirup & 61 & 30.5 \\
\hline Ditelan & 23 & 11.5 \\
\hline Injeksi & 20 & 10.0 \\
\hline
\end{tabular}

Berdasarkan data subjek penelitian sebanyak 200 klien rehab didapatkan hasil karakteristik responden berdasarkan umur diketahui umur responden 29 tahun dengan rata-rata (mean) 29.18 tahun \pm 9.637 . Diketahui lama penggunaan narkoba responden selama 5 tahun dengan rata-rata (mean) 4.19 tahun \pm 2.663 , berjenis kelamin laki-laki $(78 \%)$, berpendidikan SMA $(42 \%)$, pekerjaan responden diketahui wiraswasta $(46 \%)$, status perkawinan klien rata-rata belum menikah (48.0\%). Tempat tinggal pasien diketahui bersama orang tua atau keluarga (55.5\%). Diketahui klien yang pernah melakukan rehabilitasi diklinik rehab rawat jalan $(55.5 \%)$ serta klien yang pernah mengikuti program rehabilitasi sebanyak 1 kali (48.6\%). Jenis narkoba yang sering digunakan klien yaitu sabu $(58 \%)$ dengan cara pakai dihisap.

Tabel. 2 Hasil Uji Korelasi $(\mathrm{N}=200)$

\begin{tabular}{|c|c|c|c|c|c|c|}
\hline \multirow{3}{*}{ Dukungan Sosial } & \multicolumn{4}{|c|}{ Motivasi Untuk Sembuh } & \multirow{3}{*}{$p$-value } & \multirow{3}{*}{ OR } \\
\hline & \multicolumn{2}{|c|}{ Tinggi } & \multicolumn{2}{|c|}{ Rendah } & & \\
\hline & $\mathrm{n}$ & $\%$ & $\mathrm{n}$ & $\%$ & & \\
\hline Buruk & 45 & $22.5 \%$ & 31 & $15.0 \%$ & 0108 & $1276(0716-273)$ \\
\hline Baik & 66 & $33.0 \%$ & 58 & $29.0 \%$ & 0.408 & $1.216(0.176-2.273)$ \\
\hline
\end{tabular}


Dukungan sosial dengan motivasi berhenti menggunakan narkoba pada klien rehab rawat jalan di Badan Narkotika Nasional (BNN) Provinsi Lampung

Pada tabel 2 dapat dilihat responden yang mendapat dukungan sosial buruk sebanyak 76 responden $(38 \%)$ didapat 45 responden $(22.5 \%)$ memiliki motivasi ingin sembuh tinggi, dan 31 responden $(15.0 \%)$ memiliki motivasi ingin sembuh rendah. Responden yang memiliki dukungan keluarga baik sebanyak 66 responden (33.0\%), dan 58 responden $(29.0 \%)$ memiliki motivasi ingin sembuh tinggi, 58 responden $(29.0 \%)$ memiliki motivasi ingin sembuh rendah.

Hasil uji hipotesis dengan teknik Analisis Product Momen dari Spearman di peroleh hasil nilai $r x y$ sebesar 0,539 dengan $p=0,000$ dimana ( $p<0,01$ ) artinya ada hubungan positif yang sangat signifikan antara dukungan sosial dengan motivasi berhenti menggunakan narkoba pada klien rehab rawat jalan BNN Provinsi Lampung.

Selanjutnya pada tabel 2 hasil uji statistik menggunakan uji chi square didapat nilai $p$-value $=$ 0.408 yang artinya terdapat hubungan dukungan sosial dengan motivasi untuk sembuh resident penyalahgunaan narkoba di Klinik rehab rawat jalan BNN Provinsi Lampung Tahun 2020, dengan nilai $O R=1.276$ yang artinya responden yang memiliki dukungan keluarga buruk akan 1 kali beresiko memiliki motivasi untuk sembuh rendah.

\section{PEMBAHASAN}

Berdasarkan kategorisasi pada skala dukungan sosial mayoritas tingkat dukungan sosial klien rehab rawat jalan berada pada range kategori tinggi dan sangat tinggi dengan total jumlah frekuensi 124 dan persentase sebesar $62 \%$. Berdasarkan data tersebut menunjukkan bahwa banyak subjek penelitian yang memiliki dukungan sosial yang tinggi dari keluarga untuk membantu subjek menjalani rehabilitasi rawat jalan yang akan meningkatkan motivasi klien untuk berhenti menggunakan narkoba. Anggota keluarga memandang bahwa bahwa orang yang bersifat mendukung selalu siap memberikan pertolongan dan bantuan jika diperlukan, khususnya bagi anggota keluarga yang terlibat dalam penyalahgunaan narkoba dan harus menjalani rehabilitasi (Rahmadani, 2020).

Kategorisasi motivasi berhenti menggunakan narkoba distribusi subjek penelitian mayoritas berada pada kategori range sedang dan tinggi dengan jumlah subjek sebanyak 111 orang dengan persentase $55.5 \%$, hal ini menunjukkan semakin tingginya dukungan sosial akan mempengaruhi motivasi subjek untuk mengikuti proses rehab rawat jalan sebagai proses untuk berhenti menggunakan narkoba.

Berdasarkan hasil analisis aspek pada variabel motivasi berhenti menggunakan narkoba aspek pengakuan terhadap masalah memiliki sumbangan efektif yang paling besar memberikan pengaruh pada motivasi berhenti menggunakan narkoba sebesar $41 \%$. Salah satu aspek dari motivasi seseorang berhenti menggunakan narkoba adalah adanya pengakuan terhadap masalah dimana pada aspek ini individu menyadari masalah dari penggunaan narkoba, yang disebabkan oleh kemungkinan dorongan intrinsik individu untuk terbebas dari narkoba (Putra, 2011).

\section{SIMPULAN}

Berdasarkan hasil penelitian dan pembahasan, maka dapat diambil beberapa kesimpulan, sebagai berikut : Terdapat hubungan antara dukungan sosial dengan motivasi berhenti menggunakan narkoba pada klien rehab rawat jalan di BNN Provinsi Lampung artinya ada hubungan positif yang sangat signifikan antara dukungan sosial dengan motivasi berhenti menggunakan narkoba pada klien rehab rawat inap BNN Provinsi Lampung. Hasil tersebut menunjukkan semakin tinggi dukungan sosial khususnya dari keluarga maka semakin tinggi motivasi klien untuk berhenti menggunakan narkoba, sebaliknya semakin rendah dukungan sosial keluarga maka semakin kecil motivasi klien untuk berhenti menggunakan narkoba.

Berdasarkan kategorisasi tingkat dukungan sosial mayoritas tinggi dan sangat tinggi dengan total jumlah dari kedua kategori tersebut sebanyak 124 dan persentase sebesar $62 \%$. Untuk tingkat motivasi berhenti menggunakan narkoba mayoritas berada pada kategori sedang dan tinggi dengan jumlah subjek sebanyak 111 orang dengan persentase $55.5 \%$.

Hasil analisis aspek pada variabel motivasi berhenti menggunakan narkoba aspek pengakuan terhadap masalah memiliki sumbangan efektif yang paling besar memberikan pengaruh pada motivasi berhenti menggunakan narkoba sebesar $41 \%$

\footnotetext{
Supriyati ${ }^{1 *}$, Mutia Pangesti ${ }^{2}$

'Program Studi Psikologi Fakultas Kedokteran, Universitas Malahayati. *Email: supriyati@malahayati.ac.id

${ }^{2}$ Psikologi Klinis Ahli Pertama Bid. Rehabilitasi BNN Provinsi Lampung
} 
Dukungan sosial dengan motivasi berhenti menggunakan narkoba pada klien rehab rawat jalan di Badan Narkotika Nasional (BNN) Provinsi Lampung

\section{SARAN}

Berdasarkan hasil penelitian ini dapat menjadi dasar untuk membuat treatment bagi BNN Provinsi Lampung untuk membuat program dengan pelatihan motivasi bagi para klien rehab rawat jalan sebagai upaya untuk selalu mempertahankan motivasi klien agar dapat berhenti menggunakan narkoba. Bagi orang tua ataupun keluarga dapat dilakukan psikoedukasi tentang pentingnya peran dukungan sosial dari keluarga untuk membantu proses penyembuhan klien rehab rawat jalan dari penyalahgunaan narkoba.

\section{DAFTAR PUSTAKA}

Azwar, S. (2013). Penyusunan Skala Psikologi: Edisi Kedua. Yogyakarta: Pustaka Pelajar

Afriani, M. S., \& Sari, K. A. K. (2017). Proses Pengambilan Keputusan Untuk Berhenti Menggunakan Narkoba Pada Mantan Pecandu Narkoba Di Wilayah Denpasar. Archive Of Community Health, 4(2), 19-27.

Badan Narkotika Nasional Provinsi Lampung. (2016). Pengaruh Narkoba di Kalangan Remaja. BNNP Lampung. Lampung.

Badan Narkotika Nasional Provinsi Lampung. (2019). Data Jumlah Kasus Narkoba Di Lampung Dari Bulan Juni-Juli. BNNP Lampung. Lampung.

Badan Narkotika Nasional Republik Indonesia. (2018). Krisis Opioid, Penyalahgunaan Narkoba Meningkat; Kokain dan opium mencatatkan rekor tinggi (UNODC)). Jakarta : BNN

Chaplin, J. P. (2006). Kamus lengkap psikologi (terjemahan Kartini Kartono). Jakarta: PT Raja Grafindo Persada.

Friedman, R., Kane, M., \& Cornfield, D. B. (1998). Social support and career optimism: Examining the effectiveness of network groups among black managers. Human Relations, 51(9), 1155-1177.

Hawari, D. (2009). Penyalahgunaan dan Ketergantungan NAZA Edisi Kedua. Jakarta: FK Ul.
Kementerian Kesehatan Republik Indonesia. (2004). Modul Pelatihan Teknis Medis Masalah Penyalahgunaan Narkoba, Psikotropika, dan Bahan Adiktif Lainnya. Jakarta : BNN

Kementerian Kesehatan Republik Indonesia. (2017). Laporan Hasil Penelitian BNN dan Universitas Indonesia. Jakarta : Data Puslitdatin dan UI

Nevid, J. S., Rathus, S. A. \& Greene. (1994). Abnormal Psychology in a Changing Wold.

Putra, B. S. (2011). Hubungan antara dukungan sosial dengan motivasi untuk sembuh pada pengguna napza di rehabilitas mandani mental Health Care.

Ramadhani, A. N. (2020). Hubungan antara self efficacy dan dukungan keluarga dengan motivasi belajar pada siswa SMA (Doctoral dissertation, UIN Raden Intan Lampung).

Santrock, J. W. (2002). Life-span development.

Sarafino, E. P., \& Smith, T. W. (2014). Health psychology: Biopsychosocial interactions. John Wiley \& Sons.

Somar, L. (2001). Rehabilitasi pecandu narkoba. Jakarta: PT. Gramedia Widiasarana Yayasan Kasih Mulia.

Tarigan, I. J. (2017). Peran Badan Narkotika Nasional dengan Organisasi Sosial Kemasyarakatan dalam Penanganan Pelaku Penyalahgunaan Narkotika. Deepublish.

Uno, H. B. (2008). Teori motivasi \& pengukurannya. Jakarta: Bumi Aksara.

Weiss, R. D., Griffin, M. L., \& Mirin, S. M. (1992). Drug abuse as self-medication for depression: An empirical study. The American journal of drug and alcohol abuse, 18(2), 121-129.

Wibowo, H. (2004). Dukungan sosial sebagai variabel pemoderasi hubungan antara tekanan keluarga dengan kepuasan kerja dan kepuasan keluarga: studi pada karyawan perbankan di Surakarta.

\footnotetext{
Supriyati ${ }^{1 *}$, Mutia Pangesti ${ }^{2}$

'Program Studi Psikologi Fakultas Kedokteran, Universitas Malahayati. *Email: supriyati@malahayati.ac.id

${ }^{2}$ Psikologi Klinis Ahli Pertama Bid. Rehabilitasi BNN Provinsi Lampung
}

DOI: https://doi.org/10.33024/hjk.v15il.3791 